DOI: $10.17805 /$ zpu.2019.3.11

\title{
Вуз, организация учебного процесса в нем: удовлетворенность и ожидания студентов
}

\author{
С. В. ЛУКОВ \\ МОСКОВСКИЙ ГУМАНИТАРНЫЙ УНИВЕРСИТЕТ
}

Статья представляет данные опроса студентов Московского гуманитарного университета, проведенного в феврале - марте 2019 г. Опрос составлял обязательную часть государственной аккредитации вуза по разработанным в Рособрнадзоре инструментариям и был направлен на выявление удовлетворенности обучающихся вузом, качеством образования в нем. Хотя опрос такого рода не является эмпирическим социологическим исследованием, его данные могут быть использованы в социологии молодежи, социологии образования и т. д. для вторичного анализа данных. Показано, что недостатки инструментария (отсутствие социально-демографического блока, отнесение одной шкалы к двум вопросам, неполнота шкал) в этом случае чаще всего не мешают при сопоставлении данных внутри опроса (с учетом разницы в направлениях подготовки) и вне его (имея в виду данные других опросов) использовать этот массив в аспекте выявления удовлетворенностей и ожиданий.

Однако должен учитываться и Хоторнский эффект, который в этом случае связывается с идентификацией значительной части обучаемых со «своим» вузом, что несколько повышает (на 2-4\%) показатели удовлетворенности им и его образовательными возможностями и деятельностью.

Ключевые слова: молодежь; студенты; учебный процесс; качество образования; ожидания; удовлетворенность

\section{ВВЕАЕНИЕ}

R феврале - марте 2019 г. в Московском гуманитарном университете в связи с государственной аккредитацией образовательных программ вуза проводилось изучение отношения студентов ко многим сторонам как самого вуза, так и его возможностей и реалий их применения к повышению качества образования. По сути, в этом 
аспекте устанавливалась удовлетворенность учебой в вузе в свете ожиданий обучающихся.

Удовлетворенность преимущественно представляется как термин психологии (Большой ... , 2004). Под ним понимается субъективная оценка качества тех или иных объектов, условий жизни и деятельности, жизни в целом, отношений с людьми, самих людей, в том числе и самого себя (самооценка) (там же: 555-556). Удовлетворенность нередко рассматривается как более мягкая и более экспериментальная форма счастья (Eisenblatt, 2002: 292). В позитивной психологии - новом направлении психологических исследований, получившем признание после 1998 г., - особое внимание исследователей привлечено к тому, что могло бы способствовать тому, чтобы жизнь (в субъективном смысле) становилась лучше, или к тому, что формировало бы в людях повышенное положительное настроение и общее удовлетворение от их жизни (Seligman, Csikszentmilhalyi, 2000). Но в данном случае удовлетворенность обучающихся - лишь один из показателей качества образования, который применяется при принятии решения о судьбе вуза (например, его закрытии, лишении права преподавания по определенным образовательным программам или на определенных уровнях обучения и т. А. либо, напротив, сохранении вуза и его образовательных программ на последующие годы вплоть до очередной государственной аккредитации). Он, таким образом, из психологического обозначения определенных субъективных оценок становится инструментом управления, объективные (например, пол, возраст, образ жизни) и субъективные (темперамент, скорость реакции, жизненные установки, мотивы деятельности и т. А.) качества конкретных людей теряют значение, важны только усредненные свидетельства удовлетворенности/неудовлетворенности. Таким образом, показатель «социологизируется», он учитывается сам по себе, теряя связь с целостностью личности. Но он имеет значение среди показателей, исчисляемых по представляемым вузом данным относительно условий предоставления качественного образования, поскольку в нем все же есть следы субъективизации образовательного пространства. В этой части он сближается с изучаемыми в социологии труда трудовой удовлетворенности (англ. job satisfaction) и удовлетворенности браком (англ. marital satisfaction) в социологии семьи.

То же относится к аккредитационному пониманию ожиданий. «Ожидания» в русском языке толкуются как надежды на что-либо, расчеты, предположения (Толковый ..., 2007: 774; Словарь ..., 1983: 600). В более ранней версии, отмеченной в Толковом словаре В. И. Ааля, нет слова «ожидать» и связанных с ним существительных, но есть слово «обжидать», известное русским в форме «обождать». Оно толкуется именно в последнем смысле: «вы(со, пере, под)жидать, ждать несколько времени» (Ааль, 2007: 482). В инструментарии, примененном к обучающимся в вузе, имеется в виду тот смысл, что ожидания - это выстроенное заранее обучающимся предположение, подтверждение которого вызывает чувство удовлетворения, а если реальность оказывается иной, то возникает разочарование, досада. Это скорее социологическое представление, но в действительности связь с социологией здесь видимая. Вовсе не наблюдение за студентами вуза в аналитических, исследовательских целях имеется в виду, например, когда задается вопрос «Соответствует ли структура программы Вашим ожиданиям? (присутствуют все дисциплины, изучение которых, по Вашему мнению, необходимо для ведения будущей профессиональной деятельности; нет дублирования дисциплин; нет нарушения логики преподавания дисциплин и т. п.». Такой вопрос уместно задать тем, кто пришел на курсы переподготовки, на курсы повышения ква- 
лификации: они имеют опыт работы в данной сфере деятельности, по каким-либо причинам им предстоит снова погрузиться в учебу по направлению подготовки, специальности. Они компетентны говорить о совпадении реального учебного процесса с их ожиданиями. Что может сказать только что пришедший из средней школы 17-летний студент о необходимости преподавания дисциплин, изучение которых «необходимо для ведения будущей профессиональной деятельности», что он знает о дублировании дисциплин, о логике их преподавания? Инструментарий не учитывает пола и возраста обучаемых, другие данные о них, обычно представленные в социально-демографическом блоке (национальность, уровень доходов, особенности проживания и др., зависящие от гипотезы исследователя). Это делает анкетный опрос по представленному Рособрнадзором инструментарию вовсе не социологическим.

Вновь видна установка опроса выступить одним из показателей качества обучения в вузе, на основе которых будет принято управленческое решение относительно дальнейшей судьбы данного вуза. Однако особенности опроса не должны пониматься как его заведомая непригодность для исследовательских целей в различных отраслях социологии. В определенном смысле его данные полезны для вторичного анализа. Исходя из этого, они могут быть проанализированы и сопоставлены как внутри опроса (например, соотношение ответов по направлениям подготовки, отнесенным к ведению одного деканата, когда административный ресурс не может существенно влиять на имеющиеся данные), так и в порядке работы с иными данными, имеющимися у исследователя, в том числе полученными в собственно социологических исследованиях.

Возможно, в данном случае были все необходимые стадии проектирования эмпирического исследования: была программа исследования, выбирались адекватные методы, планировалась выборка и т. д. Но проведение исследования не сопровождается прояснением программных положений. Единственно, что известно: каждое направление подготовки должно быть представлено не менее $80 \%$ обучающихся на нем. Этот формальный подход тем не менее позволяет считать, что применен сплошной опрос, а это довольно редко можно обеспечить, если не будет подобного требования «сверху».

В данном исследовании были опрошены 2126 преподавателей (с учетом того, что один преподаватель может вести занятия по нескольким учебным предметам и, таким образом, будет учитываться в числе преподавателей по тому или иному направлению подготовки несколько раз; то же касается преподавателей, ведущих сходные предметы по разным направлениям подготовки) и 4018 обучающихся в МосГУ и его колледже, в том числе 2995 студентов трех уровней высшего образования: учащихся по образовательным программам бакалавриата (2573), магистрантов (351) и аспирантов (71). Ниже показаны данные по категориям обучающихся в высшей школе.

Среди обучающихся по программам бакалавриата представлены 25 направлений подготовки (специальностей). По направлению «экономика» 33,1\% составили очники, $1,7 \%$ - обучающиеся по очно-заочной форме, $65,2 \%$ - заочники. Соответственно по направлениям подготовки (специальностям): «менеджмент» - 40,5, 2,4 и 57,1\%; «управление персоналом» - 27,2, 2,9 и 69,9\% и др. В целом по бакалавриату данные получены от обучающихся, 48,1\% которых составили очники; 8,0\%, - обучающиеся по очно-заочной форме и 43,9\% - заочники. Опрашивались представители всех курсов: 1 -го $-22,9 \%$; 2-го $-13,3 \%$; 3-го - 32,6\%; 4-го - 31,2\%.

Из опрошенного 351 магистранта $13,7 \%$ составили очники, 6,8\% - обучающиеся по очно-заочной форме, 79,5\% - заочники. 
Среди аспирантов, а их в опросе было 71, представлены все направления, по которым ведется в МосГУ обучение по программам подготовки научно-педагогических кадров в аспирантуре.

\section{ААННЫЕ ИССАЕАОВАНИЯ}

В данных исследования все строки содержат процентные распределения. Вопросы, в которых не содержатся оценки обучающихся, отражающие их удовлетворенность учебным процессом или ожидания от него, удалены.

В исследовании использовались разные инструментарии для студентов бакалавриата, магистрантов и аспирантов (в соответствии с предписаниями Рособрнадзора), поэтому вопросы, направленные на выявление удовлетворенности учебным процессом, по уровням образования не совпадают.

Обучающиеся по программам бакалавриата представлены следующим образом.

\begin{tabular}{|c|c|c|c|c|c|}
\hline \multirow{2}{*}{$\begin{array}{l}\text { Укажите Ваше } \\
\text { направление } \\
\text { подготовки } \\
\text { (спечиальность) }\end{array}$} & \multicolumn{5}{|c|}{ 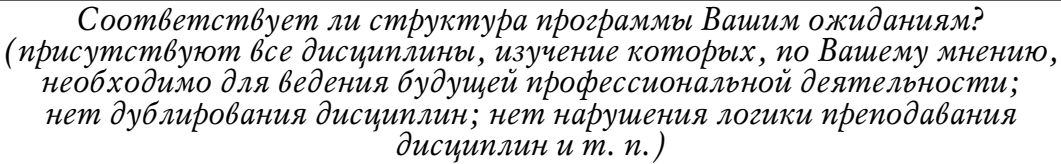 } \\
\hline & $\begin{array}{c}\text { полностью } \\
\text { соответ- } \\
\text { cmвует }\end{array}$ & $\begin{array}{c}\text { в основном } \\
\text { соответ- } \\
\text { ствует }\end{array}$ & $\begin{array}{l}\text { в большей } \\
\text { мере не } \\
\text { coombem- } \\
\text { cmbyem }\end{array}$ & $\begin{array}{c}\text { не coombem- } \\
\text { cmbyem }\end{array}$ & $\begin{array}{c}\text { затрудняюсь } \\
\text { ответить }\end{array}$ \\
\hline экономика & 82,6 & 13,2 & 2,2 & 0,2 & 1,7 \\
\hline менеджмент & 79,2 & 17,3 & 2,4 & - & 1,2 \\
\hline $\begin{array}{l}\text { управление } \\
\text { персоналом }\end{array}$ & 68,9 & 25,2 & 2,9 & - & 2,9 \\
\hline $\begin{array}{l}\text { государственное } \\
\text { и муниципальное } \\
\text { управление }\end{array}$ & 71,7 & 26,0 & 1,2 & 1,2 & - \\
\hline торговое дело & 81,8 & 9,1 & - & 4,5 & 4,5 \\
\hline $\begin{array}{l}\text { прикладная } \\
\text { информатика }\end{array}$ & 64,3 & 25,7 & 4,3 & 1,4 & 4,3 \\
\hline журналистика & 42,5 & 53,0 & 2,7 & 0,5 & 1,4 \\
\hline $\begin{array}{l}\text { реклама и связи } \\
\text { с общественностью }\end{array}$ & 61,8 & 35,4 & 2,0 & 0,4 & 0,4 \\
\hline дизайн & 62,0 & 33,8 & 1,4 & - & 2,8 \\
\hline психология & 84,1 & 13,0 & 2,9 & - & - \\
\hline $\begin{array}{l}\text { психолого-педаго- } \\
\text { гическое образо- } \\
\text { вание }\end{array}$ & 85,5 & 9,7 & 1,6 & 1,6 & 1,6 \\
\hline социология & 100,0 & - & - & - & - \\
\hline социальная работа & 100,0 & - & - & - & - \\
\hline лингвистика & 53,8 & 46,2 & - & - & - \\
\hline туризм & 57,8 & 37,8 & 2,2 & - & 2,2 \\
\hline гостиничное дело & 67,4 & 29,2 & - & - & 3,4 \\
\hline $\begin{array}{l}\text { международные } \\
\text { отношения }\end{array}$ & 57,0 & 38,7 & 1,4 & 0,7 & 2,1 \\
\hline
\end{tabular}




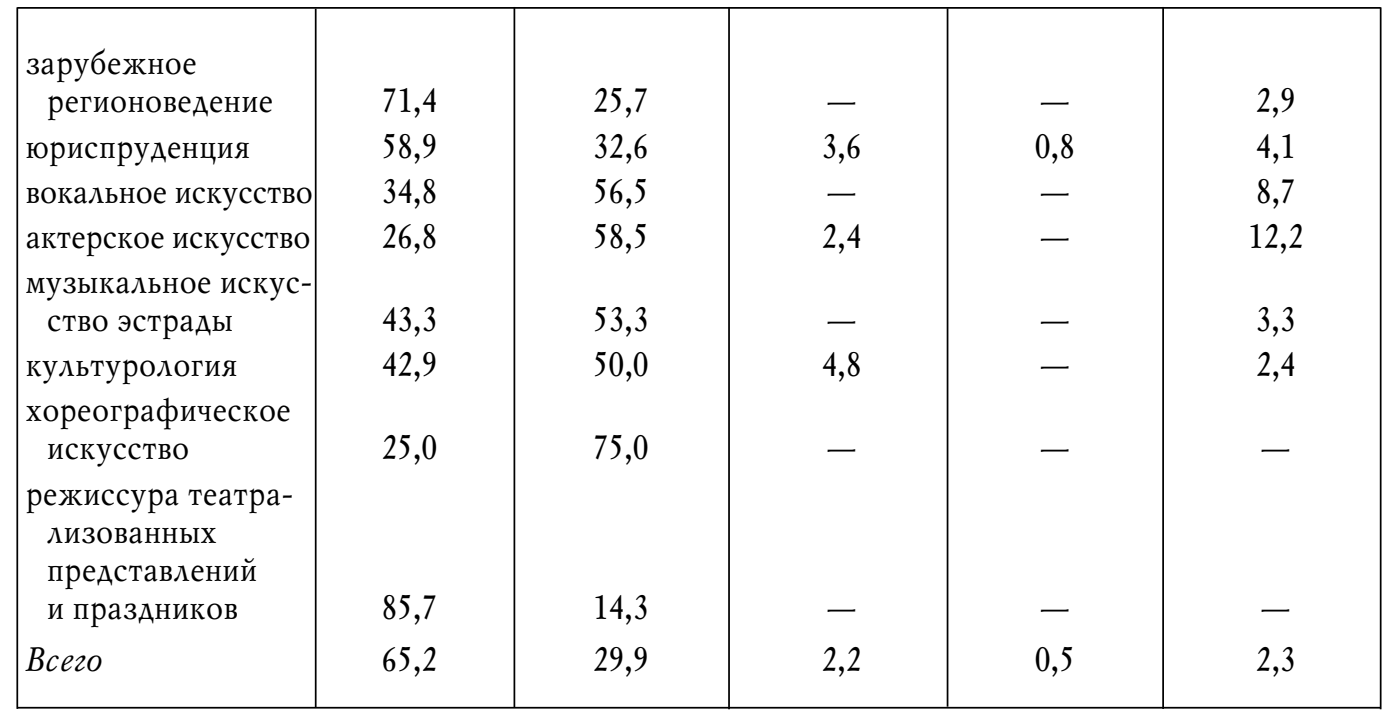

\begin{tabular}{|c|c|c|c|}
\hline \multirow{2}{*}{$\begin{array}{c}\text { Укажите Ваше направление подготовки } \\
\text { (спещиальность) }\end{array}$} & \multicolumn{3}{|c|}{$\begin{array}{c}\text { Предоставлялась ли Вам возможность } \\
\text { Выюбора дисчииллин? }\end{array}$} \\
\hline & $\partial a$ & нет & $\begin{array}{c}\text { затрудняюсь } \\
\text { ответить }\end{array}$ \\
\hline экономика & 85,3 & 10,0 & 4,7 \\
\hline менеджмент & 83,3 & 12,5 & 4,2 \\
\hline управление персоналом & 76,7 & 16,5 & 6,8 \\
\hline государственное и муниципальное управление & 76,3 & 19,1 & 4,6 \\
\hline торговое дело & 90,9 & 4,5 & 4,5 \\
\hline прикладная информатика & 71,4 & 20,0 & 8,6 \\
\hline журналистика & 90,9 & 3,2 & 5,9 \\
\hline реклама и связи с общественностью & 97,2 & 0,4 & 2,4 \\
\hline дизайн & 91,5 & 8,5 & - \\
\hline психология & 92,8 & 2,9 & 4,3 \\
\hline психолого-педагогическое образование & 88,7 & 6,5 & 4,8 \\
\hline социология & 89,5 & 5,3 & 5,3 \\
\hline социальная работа & 100,0 & - & - \\
\hline лингвистика & 84,6 & 7,7 & 7,7 \\
\hline туризм & 83,3 & 6,7 & 10,0 \\
\hline гостиничное дело & 88,8 & 6,7 & 4,5 \\
\hline международные отношения & 95,1 & 3,5 & 1,4 \\
\hline зарубежное регионоведение & 94,3 & 2,9 & 2,9 \\
\hline юриспруденция & 58,9 & 26,9 & 14,2 \\
\hline вокальное искусство & 95,7 & - & 4,3 \\
\hline
\end{tabular}




\begin{tabular}{|l|c|c|c|}
\hline актерское искусство & 68,3 & 7,3 & 24,4 \\
музыкальное искусство эстрады & 76,7 & 10,0 & 13,3 \\
культурология & 71,4 & 14,3 & 14,3 \\
хореографическое искусство & 75,0 & 25,0 & - \\
режиссура театрализованных & & & \\
представлений и праздников & 57,1 & - & 42,9 \\
Всего & 82,0 & 11,2 & 6,8 \\
\hline
\end{tabular}

\begin{tabular}{|c|c|c|c|c|}
\hline \multirow{2}{*}{$\begin{array}{c}\text { Укажите Ваше направление } \\
\text { подготовки (спечиальность) }\end{array}$} & \multicolumn{4}{|c|}{$\begin{array}{c}\text { Всегда ли доступна Вам вся необходимая } \\
\text { информауия, касаюшаяся учебного прочесса, } \\
\text { внеучебных мероприятии? }\end{array}$} \\
\hline & $\begin{array}{c}\partial a, \\
\text { вcezda }\end{array}$ & $\begin{array}{c}\text { нет, } \\
\text { не всегда }\end{array}$ & $\begin{array}{c}\text { затрудняюсь } \\
\text { ответить }\end{array}$ & другоe \\
\hline экономика & 90,9 & 6,6 & 2,5 & - \\
\hline менеджмент & 92,3 & 2,4 & 5,4 & - \\
\hline управление персоналом & 95,1 & 2,9 & 1,0 & 1,0 \\
\hline государственное и муниципальное & & & & \\
\hline управление & 90,8 & 3,5 & 4,6 & 1,2 \\
\hline торговое дело & 86,4 & 4,5 & 9,1 & - \\
\hline прикладная информатика & 92,9 & 7,1 & - & - \\
\hline журналистика & 90,4 & 4,6 & 4,6 & 0,5 \\
\hline реклама и связи с общественностью & 95,5 & 0,4 & 4,1 & - \\
\hline дизайн & 94,4 & - & 5,6 & - \\
\hline психология & 95,7 & 4,3 & - & - \\
\hline психолого-педагогическое образование & 93,5 & 4,8 & 1,6 & - \\
\hline социология & 100,0 & - & - & - \\
\hline социальная работа & 100,0 & - & - & - \\
\hline лингвистика & 92,3 & - & 7,7 & - \\
\hline туризм & 84,4 & 11,1 & 4,4 & - \\
\hline гостиничное дело & 87,6 & 6,7 & 5,6 & - \\
\hline международные отношения & 79,6 & 16,2 & 4,2 & - \\
\hline зарубежное регионоведение & 94,3 & 5,7 & - & - \\
\hline юриспруденция & 82,4 & 8,3 & 8,5 & 0,8 \\
\hline вокальное искусство & 100,0 & - & - & - \\
\hline актерское искусство & 85,4 & 7,3 & 7,3 & - \\
\hline музыкальное искусство эстрады & 56,7 & 26,7 & 13,3 & 3,3 \\
\hline культурология & 76,2 & 21,4 & 2,4 & - \\
\hline хореографическое искусство & 87,5 & 12,5 & - & - \\
\hline режиссура театрализованных & & & & \\
\hline представлений и праздников & 57,1 & 14,3 & 28,6 & - \\
\hline Bcero & 88,6 & 6,5 & 4,6 & 0,3 \\
\hline
\end{tabular}




\begin{tabular}{|c|c|c|c|}
\hline \multirow{2}{*}{$\begin{array}{c}\text { Укажите Ваше направление подготовки } \\
\text { (спечиальность) }\end{array}$} & \multicolumn{3}{|c|}{$\begin{array}{l}\text { Если ли у Вас возможность подключения } \\
\text { к электронно-библиотечной системе вуза } \\
\text { из любой точки, где есть сеть Интернет? }\end{array}$} \\
\hline & $\partial a, b c e z \partial a$ & $\begin{array}{c}\text { не всегда } \\
\text { получается }\end{array}$ & нет \\
\hline экономика & 95,3 & 4,2 & 0,5 \\
\hline менеджмент & 94,0 & 4,8 & 1,2 \\
\hline управление персоналом & 97,1 & 1,9 & 1,0 \\
\hline государственное и муниципальное управление & 93,0 & 5,2 & 1,7 \\
\hline торговое дело & 100,0 & - & - \\
\hline прикладная информатика & 97,1 & 2,9 & - \\
\hline журналистика & 95,4 & 4,1 & 0,5 \\
\hline реклама и связи с общественностью & 100,0 & - & - \\
\hline дизайн & 98,6 & 1,4 & - \\
\hline психология & 98,6 & 1,4 & - \\
\hline психолого-педагогическое образование & 100,0 & - & - \\
\hline социология & 100,0 & - & - \\
\hline социальная работа & 100,0 & - & - \\
\hline лингвистика & 69,2 & 30,8 & - \\
\hline туризм & 91,1 & 8,9 & - \\
\hline гостиничное дело & 77,5 & 22,5 & - \\
\hline международные отношения & 85,2 & 14,8 & - \\
\hline зарубежное регионоведение & 82,9 & 17,1 & - \\
\hline юриспруденция & 88,1 & 10,4 & 1,6 \\
\hline вокальное искусство & 60,9 & 39,1 & - \\
\hline актерское искусство & 58,5 & 41,5 & - \\
\hline музыкальное искусство эстрады & 70,0 & 26,7 & 3,3 \\
\hline культурология & 76,2 & 23,8 & - \\
\hline хореографическое искусство & 75,0 & 25,0 & - \\
\hline $\begin{array}{c}\text { режиссура театрализованных } \\
\text { представлений и праздников }\end{array}$ & 71,4 & 28,6 & - \\
\hline Всего & 91,4 & 7,9 & 0,7 \\
\hline
\end{tabular}

\begin{tabular}{|c|c|c|}
\hline \multirow[t]{2}{*}{$\begin{array}{c}\text { Укажите Ваше направление подготовки } \\
\text { (специальность) }\end{array}$} & \multicolumn{2}{|c|}{$\begin{array}{c}\text { Аоступны ли Вам учебники, } \\
\text { методическе пособия, лекиии и т. д. } \\
\text { в электронной и печатной формах? }\end{array}$} \\
\hline & $\partial a$ & Hem \\
\hline экономика & 98,0 & 2,0 \\
\hline менеджмент & 97,0 & 3,0 \\
\hline управление персоналом & 98,1 & 1,9 \\
\hline государственное и муниципальное управление & 97,7 & 2,3 \\
\hline
\end{tabular}




\begin{tabular}{|l|c|c|}
\hline торговое дело & 100,0 & - \\
прикладная информатика & 95,7 & 4,3 \\
журналистика & 99,1 & 0,9 \\
реклама и связи с общественностью & 99,6 & - \\
дизайн & 100,0 & - \\
психология & 100,0 & 3,2 \\
психолого-педагогическое образование & 96,8 & - \\
социология & 100,0 & - \\
социальная работа & 100,0 & - \\
лингвистика & 100,0 & - \\
туризм & 100,0 & - \\
гостиничное дело & 100,0 & - \\
международные отношения & 100,0 & 3,2 \\
зарубежное регионоведение & 100,0 & - \\
юриспруденция & 96,8 & - \\
вокальное искусство & 100,0 & - \\
актерское искусство & 100,0 & - \\
музыкальное искусство эстрады & 94,9 & 2,4 \\
культурология & 97,6 & - \\
хореографическое искусство & 100,0 & -7 \\
режиссура театрализованных представлений & 100,0 \\
и праздников & 98,3 & - \\
Всего & & - \\
\hline
\end{tabular}

\begin{tabular}{|c|c|c|c|c|}
\hline \multirow[b]{2}{*}{$\begin{array}{c}\text { Укажите Ваше направление } \\
\text { подготовки (спещиальность) }\end{array}$} & \multicolumn{4}{|c|}{ Как Вы можете оченить их качество? } \\
\hline & $\begin{array}{l}\text { полностью } \\
\text { удовлетво- } \\
\text { рен }(\text { a) }\end{array}$ & $\begin{array}{c}\text { удовлетво- } \\
\text { рен(а) } \\
\text { в большей мере }\end{array}$ & $\begin{array}{c}\text { не в полной } \\
\text { мере }\end{array}$ & $\begin{array}{c}\text { не удовлетво- } \\
\text { рен (a) }\end{array}$ \\
\hline экономика & 81,0 & 16,5 & 2,5 & - \\
\hline менеджмент & 82,6 & 14,4 & 2,4 & 0,6 \\
\hline управление персоналом & 76,7 & 23,3 & - & - \\
\hline $\begin{array}{l}\text { государственное и муниципальное } \\
\text { управление }\end{array}$ & 74,0 & 22,0 & 3,5 & 0,6 \\
\hline торговое дело & 86,4 & 13,6 & - & - \\
\hline прикладная информатика & 71,0 & 23,2 & 5,8 & - \\
\hline журналистика & 54,8 & 43,4 & 1,8 & - \\
\hline $\begin{array}{l}\text { реклама и связи с обществен- } \\
\text { ностью }\end{array}$ & 68,3 & 30,5 & 1,2 & - \\
\hline дизайн & 67,6 & 32,4 & - & - \\
\hline
\end{tabular}




\begin{tabular}{|l|c|c|c|c|}
\hline психология & 82,6 & 14,5 & 2,9 & - \\
психолого-педагогическое & & & - & - \\
образование & 85,5 & 14,5 & - & - \\
социология & 100,0 & - & - & - \\
социальная работа & 100,0 & - & - & - \\
лингвистика & 53,8 & 46,2 & 1,1 & - \\
туризм & 65,6 & 33,3 & 1,1 & - \\
гостиничное дело & 47,2 & 51,7 & 1,4 & - \\
международные отношения & 63,4 & 35,2 & 2,9 & - \\
зарубежное регионоведение & 65,7 & 31,4 & 6,2 & - \\
юриспруденция & 59,4 & 33,1 & - & 1,7 \\
вокальное искусство & 26,1 & 73,9 & 2,4 & - \\
актерское искусство & 39,0 & 58,5 & 1,7 & - \\
музыкальное искусство эстрады & 40,0 & 56,7 & 4,8 & \\
культурология & 59,5 & 35,7 & 12,5 & - \\
хореографическое искусство & 25,0 & 62,5 & - & 0,3 \\
режиссура театрализованных & & & 2,6 & \\
представлений и праздников & 14,3 & 85,7 & 29,4 & \\
Всего & 67,6 & & \\
\hline
\end{tabular}

\begin{tabular}{|c|c|c|c|}
\hline \multirow{2}{*}{$\begin{array}{c}\text { Укажите Ваше направление подготовки } \\
\text { (спечиальность) }\end{array}$} & \multicolumn{3}{|c|}{$\begin{array}{c}\text { Удовлетворяет ли Вашим } \\
\text { потребностям компьютерное } \\
\text { обеспечение учебного прочесса? }\end{array}$} \\
\hline & $\partial a$ & нет & не знаю \\
\hline экономика & 94,6 & 2,0 & 3,4 \\
\hline менеджмент & 94,0 & 1,8 & 4,2 \\
\hline управление персоналом & 95,1 & - & 4,9 \\
\hline государственное и муниципальное управление & 92,5 & 3,5 & 4,0 \\
\hline торговое дело & 100,0 & - & - \\
\hline прикладная информатика & 87,1 & 8,6 & 4,3 \\
\hline журналистика & 93,6 & 1,4 & 5,0 \\
\hline реклама и связи с общественностью & 97,2 & 1,2 & 1,6 \\
\hline дизайн & 97,2 & - & 2,8 \\
\hline психология & 97,1 & 1,4 & 1,4 \\
\hline психолого-педагогическое образование & 95,2 & - & 4,8 \\
\hline социология & 100,0 & - & - \\
\hline социальная работа & 100,0 & - & - \\
\hline лингвистика & 84,6 & - & 15,4 \\
\hline туризм & 96,7 & 2,2 & 1,1 \\
\hline
\end{tabular}




\begin{tabular}{|c|c|c|c|}
\hline гостиничное дело & 89,9 & 1,1 & 9,0 \\
\hline международные отношения & 93,0 & 2,8 & 4,2 \\
\hline зарубежное регионоведение & 85,7 & 11,4 & 2,9 \\
\hline юриспруденция & 88,6 & 2,3 & 9,0 \\
\hline вокальное искусство & 95,7 & - & 4,3 \\
\hline актерское искусство & 95,1 & - & 4,9 \\
\hline музыкальное искусство эстрады & 78,3 & 1,7 & 20,0 \\
\hline культурология & 88,1 & 11,9 & - \\
\hline хореографическое искусство & 100,0 & - & - \\
\hline $\begin{array}{l}\text { режиссура театрализованных представлений } \\
\text { и праздников }\end{array}$ & 85,7 & - & 14,3 \\
\hline Bcero & 92,9 & 2,2 & 4,9 \\
\hline
\end{tabular}

\begin{tabular}{|c|c|c|c|c|}
\hline \multirow{2}{*}{$\begin{array}{c}\text { Укажите Ваше направление } \\
\text { подготовки (спещиильность) }\end{array}$} & \multicolumn{4}{|c|}{$\begin{array}{c}\text { Удовлетворяет ли Вас качество аудиторий, помешении } \\
\text { кафедр, фондов читального зала и библиотеки, } \\
\text { учебньх лабораторий и оборудования? }\end{array}$} \\
\hline & $\begin{array}{l}\text { не удовле- } \\
\text { творяют }\end{array}$ & $\begin{array}{l}\text { не в полной } \\
\text { мере удовле- } \\
\text { творяют }\end{array}$ & $\begin{array}{c}\text { в большей } \\
\text { степени удов- } \\
\text { летворяют }\end{array}$ & $\begin{array}{l}\text { удовле- } \\
\text { творяют }\end{array}$ \\
\hline экономика & 1,2 & 5,9 & 22,5 & 70,3 \\
\hline менеджмент & 0,6 & 4,2 & 42,5 & 52,7 \\
\hline управление персоналом & - & 6,8 & 31,1 & 62,1 \\
\hline $\begin{array}{l}\text { государственное и муниципальное } \\
\text { управление }\end{array}$ & 2,9 & 9,2 & 38,2 & 49,7 \\
\hline торговое дело & - & - & 36,4 & 63,6 \\
\hline прикладная информатика & 1,4 & - & 44,3 & 54,3 \\
\hline журналистика & - & 3,7 & 43,8 & 52,5 \\
\hline $\begin{array}{l}\text { реклама и связи с обществен- } \\
\text { ностью }\end{array}$ & 1,2 & 1,2 & 28,5 & 69,1 \\
\hline дизайн & - & 2,8 & 31,0 & 66,2 \\
\hline психология & - & 1,4 & 13,0 & 85,5 \\
\hline $\begin{array}{l}\text { психолого-педагогическое } \\
\text { образование }\end{array}$ & - & 1,6 & 11,3 & 87,1 \\
\hline социология & - & - & - & 100,0 \\
\hline социальная работа & - & - & - & 100,0 \\
\hline лингвистика & - & 7,7 & 46,2 & 46,2 \\
\hline туризм & 2,2 & 4,4 & 34,4 & 58,9 \\
\hline гостиничное дело & - & 11,2 & 33,7 & 55,1 \\
\hline международные отношения & - & 7,0 & 33,8 & 59,2 \\
\hline зарубежное регионоведение & - & 2,9 & 31,4 & 65,7 \\
\hline
\end{tabular}




\begin{tabular}{|l|c|c|c|c|}
\hline вокальное искусство & - & - & 69,6 & 30,4 \\
актерское искусство & 2,4 & 2,4 & 63,4 & 31,7 \\
музыкальное искусство эстрады & - & 5,0 & 31,7 & 63,3 \\
культурология & 2,4 & 7,1 & 31,0 & 59,5 \\
хореографическое искусство & - & - & 50,0 & 50,0 \\
режиссура театрализованных & & - & 57,1 & 42,9 \\
представлений и праздников & - & - & 33,9 & 58,8 \\
Всего & 1,6 & 5,7 & & \\
\hline
\end{tabular}

\begin{tabular}{|c|c|c|c|c|}
\hline \multirow{2}{*}{$\begin{array}{c}\text { Укажите Ваше направление } \\
\text { подготовки (спещиальность) }\end{array}$} & \multicolumn{4}{|c|}{$\begin{array}{c}\text { Оиените, как организована самостоятельная работа } \\
\text { студентов в университете: есть ли для этого помещения, } \\
\text { компьютерное обеспечение и т. д.? }\end{array}$} \\
\hline & $\begin{array}{l}\text { не удовле- } \\
\text { творен(а) }\end{array}$ & $\begin{array}{l}\text { не в полной } \\
\text { мере удовле- } \\
\text { творен(а) }\end{array}$ & $\begin{array}{l}\text { в большей } \\
\text { степени удов- } \\
\text { летворен (а) }\end{array}$ & $\begin{array}{c}\text { удовле- } \\
\text { mворен }(a)\end{array}$ \\
\hline экономика & 0,2 & 2,2 & 20,1 & 77,5 \\
\hline менеджмент & - & 3,0 & 25,1 & 71,9 \\
\hline управление персоналом & - & 1,0 & 29,1 & 69,9 \\
\hline $\begin{array}{l}\text { государственное и муниципальное } \\
\text { управление }\end{array}$ & 2,3 & 2,9 & 34,1 & 60,7 \\
\hline торговое дело & - & - & 31,8 & 68,2 \\
\hline прикладная информатика & - & 4,3 & 37,1 & 58,6 \\
\hline журналистика & - & 3,2 & 43,4 & 53,4 \\
\hline $\begin{array}{l}\text { реклама и связи с обществен- } \\
\text { ностью }\end{array}$ & 0,8 & 0,8 & 26,4 & 72,0 \\
\hline дизайн & - & 1,4 & 28,2 & 70,4 \\
\hline психология & - & - & 15,9 & 84,1 \\
\hline $\begin{array}{l}\text { психолого-педагогическое } \\
\text { образование }\end{array}$ & - & - & 9,7 & 90,3 \\
\hline социология & - & - & - & 100,0 \\
\hline социальная работа & - & - & - & 100,0 \\
\hline лингвистика & - & - & 53,8 & 46,2 \\
\hline туризм & 2,2 & 2,2 & 32,2 & 63,3 \\
\hline гостиничное дело & - & 3,4 & 30,3 & 66,3 \\
\hline международные отношения & - & 1,4 & 35,9 & 62,7 \\
\hline зарубежное регионоведение & - & 5,7 & 25,7 & 68,6 \\
\hline юриспруденция & 1,6 & 6,8 & 37,8 & 53,9 \\
\hline вокальное искусство & - & - & 69,6 & 30,4 \\
\hline актерское искусство & - & 9,8 & 53,7 & 36,6 \\
\hline $\begin{array}{l}\text { музыкальное искусство } \\
\text { эстрады }\end{array}$ & 3,3 & 3,3 & 35,0 & 58,3 \\
\hline
\end{tabular}




\begin{tabular}{|l|c|c|c|c|}
\hline культурология & - & 12,2 & 34,1 & 53,7 \\
хореографическое искусство & - & 25,0 & 62,5 & 12,5 \\
режиссура театрализованных & & & & \\
$\quad$ представлений и праздников & - & - & 42,9 & 57,1 \\
Всего & 0,7 & 3,2 & 30,8 & 65,3 \\
\hline
\end{tabular}

\begin{tabular}{|c|c|c|c|}
\hline \multirow{2}{*}{$\begin{array}{c}\text { Укажите Ваше направление подготовки } \\
\text { (спещиальность) }\end{array}$} & \multicolumn{3}{|c|}{$\begin{array}{l}\text { Влияет ли Ваше мнение на повышение } \\
\text { качества образовательных ресурсов, } \\
\text { используемьх при реализачии программь? }\end{array}$} \\
\hline & $\partial a$ & нет & $\begin{array}{c}\text { затрудняюсь } \\
\text { ответить }\end{array}$ \\
\hline экономика & 79,9 & 5,9 & 14,2 \\
\hline менеджмент & 74,4 & 3,6 & 22,0 \\
\hline управление персоналом & 57,3 & 10,7 & 32,0 \\
\hline государственное и муниципальное управление & 68,8 & 5,8 & 25,4 \\
\hline торговое дело & 95,5 & - & 4,5 \\
\hline прикладная информатика & 64,3 & 7,1 & 28,6 \\
\hline журналистика & 74,0 & 2,7 & 23,3 \\
\hline реклама и связи с общественностью & 83,7 & 1,2 & 15,0 \\
\hline дизайн & 88,7 & 1,4 & 9,9 \\
\hline психология & 85,5 & 5,8 & 8,7 \\
\hline психолого-педагогическое образование & 88,7 & - & 11,3 \\
\hline социология & 89,5 & - & 10,5 \\
\hline социальная работа & 100,0 & - & - \\
\hline лингвистика & 69,2 & - & 30,8 \\
\hline туризм & 65,6 & 6,7 & 27,8 \\
\hline гостиничное дело & 73,0 & 2,2 & 24,7 \\
\hline международные отношения & 77,3 & 0,7 & 22,0 \\
\hline зарубежное регионоведение & 68,6 & - & 31,4 \\
\hline юриспруденция & 48,1 & 12,7 & 39,3 \\
\hline вокальное искусство & 47,8 & 4,3 & 47,8 \\
\hline актерское искусство & 34,1 & 2,4 & 63,4 \\
\hline музыкальное искусство әстрады & 45,0 & 6,7 & 48,3 \\
\hline культурология & 52,4 & 11,9 & 35,7 \\
\hline хореографическое искусство & 37,5 & - & 62,5 \\
\hline $\begin{array}{l}\text { режиссура театрализованных представлений } \\
\text { и праздников }\end{array}$ & 14,3 & - & 85,7 \\
\hline Bcero & 69,7 & 5,4 & 24,9 \\
\hline
\end{tabular}




\begin{tabular}{|c|c|c|c|}
\hline \multirow{2}{*}{$\begin{array}{c}\text { Укажите Ваше направление подготовки } \\
\text { (спечиальность) }\end{array}$} & \multicolumn{3}{|c|}{$\begin{array}{c}\text { Удовлетворены ли Вы тем, что обучаетесь } \\
\text { в данном вузе и на данном направлении } \\
\text { подготовки (спещиильности)? }\end{array}$} \\
\hline & $\begin{array}{c}\text { полностью } \\
\text { удовлетворен }(a)\end{array}$ & $\begin{array}{c}\text { частично } \\
\text { удовлетворен }(\text { a) }\end{array}$ & не знаюо \\
\hline экономика & 90,4 & 8,6 & 1,0 \\
\hline менеджмент & 89,9 & 6,5 & 3,6 \\
\hline управление персоналом & 88,3 & 10,7 & 1,0 \\
\hline $\begin{array}{l}\text { государственное и муниципальное } \\
\text { управление }\end{array}$ & 83,8 & 15,6 & 0,6 \\
\hline торговое дело & 86,4 & 13,6 & - \\
\hline прикладная информатика & 77,1 & 20,0 & 2,9 \\
\hline журналистика & 76,7 & 21,5 & 1,8 \\
\hline реклама и связи с общественностью & 85,4 & 14,2 & 0,4 \\
\hline дизайн & 85,9 & 11,3 & 2,8 \\
\hline психология & 98,6 & 1,4 & - \\
\hline психолого-педагогическое образование & 90,3 & 8,1 & 1,6 \\
\hline социология & 100,0 & - & - \\
\hline социальная работа & 100,0 & - & - \\
\hline лингвистика & 92,3 & 7,7 & - \\
\hline туризм & 82,2 & 17,8 & - \\
\hline гостиничное дело & 78,7 & 20,2 & 1,1 \\
\hline международные отношения & 87,3 & 12,0 & 0,7 \\
\hline зарубежное регионоведение & 94,3 & 5,7 & - \\
\hline юриспруденция & 78,0 & 18,9 & 3,1 \\
\hline вокальное искусство & 87,0 & 13,0 & - \\
\hline актерское искусство & 80,5 & 19,5 & - \\
\hline музыкальное искусство эстрады & 86,7 & 11,7 & 1,7 \\
\hline культурология & 81,0 & 19,0 & - \\
\hline хореографическое искусство & 75,0 & 25,0 & - \\
\hline $\begin{array}{l}\text { режиссура театрализованных } \\
\text { представлений и праздников }\end{array}$ & 42,9 & 57,1 & - \\
\hline Bcero & 84,7 & 13,8 & 1,4 \\
\hline
\end{tabular}

\begin{tabular}{|c|c|c|c|c|}
\hline \multirow{2}{*}{$\begin{array}{c}\text { Укажите Ваше направление } \\
\text { подготовки (спещиальность) }\end{array}$} & \multicolumn{4}{|c|}{$\begin{array}{c}\text { Очените качество образования по программе } \\
\text { в иелом }\end{array}$} \\
\hline & $\begin{array}{l}\text { неудовлетво- } \\
\text { рительно }\end{array}$ & $\begin{array}{c}\text { удовлетвори- } \\
\text { тельно }\end{array}$ & хорошо & отлично \\
\hline экономика & 0,7 & 5,4 & 24,5 & 69,4 \\
\hline менеджмент & - & 5,4 & 39,9 & 54,8 \\
\hline управление персоналом & - & 8,7 & 33,0 & 58,3 \\
\hline
\end{tabular}




\begin{tabular}{|l|c|c|c|c|}
\hline государственное и муниципальное & & & & \\
управление & 0,6 & 5,2 & 33,5 & 60,7 \\
торговое дело & - & 4,5 & 31,8 & 63,6 \\
прикладная информатика & 1,4 & 7,1 & 35,7 & 55,7 \\
журналистика & - & 4,1 & 42,9 & 53,0 \\
реклама и связи с общественностью & - & 2,4 & 32,5 & 65,0 \\
дизайн & - & 1,4 & 29,6 & 69,0 \\
психология & - & 4,3 & 15,9 & 79,7 \\
психолого-педагогическое & & & & \\
\multicolumn{1}{|c}{ образование } & - & - & 14,5 & 85,5 \\
социология & - & - & 5,3 & 94,7 \\
социальная работа & - & - & - & 100,0 \\
лингвистика & - & 7,7 & 30,8 & 61,5 \\
туризм & - & 8,9 & 27,8 & 63,3 \\
гостиничное дело & - & 9,0 & 33,7 & 57,3 \\
международные отношения & - & 0,7 & 30,3 & 69,0 \\
зарубежное регионоведение & - & - & 28,6 & 71,4 \\
юриспруденция & 0,3 & 10,6 & 40,6 & 48,6 \\
вокальное искусство & - & 4,3 & 78,3 & 17,4 \\
актерское искусство & - & 12,2 & 63,4 & 24,4 \\
музыкальное искусство эстрады & - & 6,7 & 41,7 & 51,7 \\
культурология & - & 11,9 & 38,1 & 50,0 \\
хореографическое искусство & - & - & 75,0 & 25,0 \\
режиссура театрализованных & - & - & 57,1 & 42,9 \\
представлений и праздников & - & 5,8 & 33,9 & 60,2 \\
Всего & -2 & & & \\
\hline
\end{tabular}

Обучающиеся по программам магистратуры представлены следующим образом (по направлениям подготовки «торговое дело», «прикладная информатика», «журналистика», «социальная работа», «лингвистика», «гостиничное дело», «дизайн» данных нет).

\begin{tabular}{|c|c|c|c|c|}
\hline \multirow[t]{2}{*}{$\begin{array}{c}\text { Укажите Ваше направление под- } \\
\text { готовки (спечиальность) }\end{array}$} & \multicolumn{4}{|c|}{$\begin{array}{c}\text { Соответствует ли структура программь Вашим } \\
\text { ожиданиял? (присутствуют все дисчиплинь, изучение } \\
\text { которых, по Вашему мнению, необхоимо для ведения } \\
\text { будущей профессиональной деятельности; нет } \\
\text { дублирования дисииплин; нет нарушения логики } \\
\text { преподавания дисчиплин и т. п.) }\end{array}$} \\
\hline & $\begin{array}{l}\text { полностью со- } \\
\text { ответствует }\end{array}$ & $\begin{array}{l}\text { В основном со- } \\
\text { ответствует }\end{array}$ & $\begin{array}{l}\text { не coombem- } \\
\text { cmbyem }\end{array}$ & $\begin{array}{c}\text { затрудняюсь } \\
\text { ответить }\end{array}$ \\
\hline экономика & 100,0 & - & - & - \\
\hline менеджмент & 93,3 & 6,7 & - & - \\
\hline управление персоналом & 93,3 & 6,7 & - & - \\
\hline
\end{tabular}




\begin{tabular}{|c|c|c|c|c|}
\hline $\begin{array}{l}\text { государственное и муниципальное } \\
\text { управление }\end{array}$ & 96,2 & 3,8 & - & - \\
\hline $\begin{array}{l}\text { реклама и связи с обществен- } \\
\text { ностью }\end{array}$ & 87,5 & 12,5 & - & - \\
\hline психология & 94,7 & 5,3 & - & - \\
\hline $\begin{array}{l}\text { психолого-педагогическое } \\
\text { образование }\end{array}$ & 86,7 & 13,3 & - & - \\
\hline социология & 100,0 & - & - & - \\
\hline туризм & 66,7 & 33,3 & - & - \\
\hline международные отношения & 76,9 & 23,1 & - & - \\
\hline зарубежное регионоведение & 100,0 & - & - & - \\
\hline юриспруденция & 78,7 & 19,7 & 0,8 & 0,8 \\
\hline культурология & 67,9 & 32,1 & - & - \\
\hline Bcero & 86,3 & 13,1 & 0,3 & 0,3 \\
\hline
\end{tabular}

\begin{tabular}{|c|c|c|c|}
\hline \multirow{2}{*}{$\begin{array}{c}\text { Укажите Ваше направление подготовки } \\
\text { (спещиальность) }\end{array}$} & \multicolumn{3}{|c|}{$\begin{array}{c}\text { Предоставлялась ли Вам возможность } \\
\text { Вььбора дисцииллин? }\end{array}$} \\
\hline & $\partial a$ & нет & $\begin{array}{l}\text { затрудняюсь } \\
\text { ответить }\end{array}$ \\
\hline экономика & 100,0 & - & - \\
\hline менеджмент & 93,3 & 6,7 & - \\
\hline управление персоналом & 93,3 & 6,7 & - \\
\hline государственное и муниципальное управление & 100,0 & - & - \\
\hline реклама и связи с общественностью & 100,0 & - & - \\
\hline психология & 100,0 & - & - \\
\hline психолого-педагогическое образование & 100,0 & - & - \\
\hline социология & 100,0 & - & - \\
\hline туризм & 66,7 & 33,3 & - \\
\hline международные отношения & 84,6 & 15,4 & - \\
\hline зарубежное регионоведение & 100,0 & - & - \\
\hline юриспруденция & 78,7 & 9,8 & 11,5 \\
\hline культурология & 96,4 & - & 3,6 \\
\hline Bcero & 90,6 & 5,1 & 4,3 \\
\hline
\end{tabular}

\begin{tabular}{|l|c|c|c|c|}
\hline \multirow{2}{*}{$\begin{array}{c}\text { Укажите Ваше направление } \\
\text { подготовки (специальность) }\end{array}$} & \multicolumn{4}{|c|}{ Участвуете ли Вы в научно-ислледовательской работе? } \\
\cline { 2 - 5 } & $\partial a$ & нет & не знаю & другое \\
\hline экономика & 100,0 & - & - & - \\
менеджмент & 96,7 & 3,3 & - & - \\
\hline
\end{tabular}




\begin{tabular}{|c|c|c|c|c|}
\hline управление персоналом & 93,3 & 6,7 & - & - \\
\hline $\begin{array}{l}\text { государственное и муниципальное } \\
\text { управление }\end{array}$ & 100,0 & - & - & - \\
\hline $\begin{array}{l}\text { реклама и связи с обществен- } \\
\text { ностью }\end{array}$ & 100,0 & - & - & - \\
\hline психология & 100,0 & - & - & - \\
\hline $\begin{array}{l}\text { психолого-педагогическое } \\
\text { образование }\end{array}$ & 100,0 & - & - & - \\
\hline социология & 100,0 & - & - & - \\
\hline туризм & 66,7 & 33,3 & - & - \\
\hline международные отношения & 100,0 & - & - & - \\
\hline зарубежное регионоведение & 100,0 & - & - & - \\
\hline юриспруденция & 86,9 & 7,4 & 4,9 & 0,8 \\
\hline культурология & 100,0 & - & - & 一 \\
\hline Bcezo & 94,6 & 3,4 & 1,7 & 0,3 \\
\hline
\end{tabular}

\begin{tabular}{|c|c|c|c|c|}
\hline \multirow{2}{*}{$\begin{array}{c}\text { Укажите Ваше направление } \\
\text { подготовки (спещиальность) }\end{array}$} & \multicolumn{4}{|c|}{$\begin{array}{c}\text { Принимаете ли Вы участие в научных семинарах, } \\
\text { конференииях в качестве докладиков } \\
\text { о результатах НИР? }\end{array}$} \\
\hline & $\partial a$ & нет & иногда & дpyzoe \\
\hline экономика & 96,6 & - & 3,4 & - \\
\hline менеджмент & 83,3 & 6,7 & 10,0 & - \\
\hline управление персоналом & 93,3 & 6,7 & - & - \\
\hline $\begin{array}{l}\text { государственное и муниципальное } \\
\text { управление }\end{array}$ & 96,2 & - & 3,8 & - \\
\hline $\begin{array}{l}\text { реклама и связи с обществен- } \\
\text { ностью }\end{array}$ & 87,5 & 6,3 & 6,3 & - \\
\hline психология & 94,7 & - & 5,3 & - \\
\hline $\begin{array}{l}\text { психолого-педагогическое } \\
\text { образование }\end{array}$ & 86,7 & 6,7 & 6,7 & - \\
\hline социология & 100,0 & - & - & - \\
\hline туризм & 33,3 & 66,7 & - & - \\
\hline международные отношения & 53,8 & - & 46,2 & - \\
\hline зарубежное регионоведение & - & - & 100,0 & - \\
\hline юриспруденция & 74,6 & 16,4 & 8,2 & 0,8 \\
\hline культурология & 82,1 & - & 17,9 & - \\
\hline Bcero & 82,6 & 7,7 & 9,4 & 0,3 \\
\hline
\end{tabular}




\begin{tabular}{|c|c|c|c|}
\hline \multirow{2}{*}{$\begin{array}{c}\text { Укажите Ваше направление подготовки } \\
\text { (спещиальность) }\end{array}$} & \multicolumn{3}{|c|}{$\begin{array}{c}\text { Всегда ли доступна Вам вся необходимая } \\
\text { информачия, касаюшаяся учебного } \\
\text { прочесса, внеучебных мероприятий? }\end{array}$} \\
\hline & $\partial a, b c e r \partial a$ & нет, не всегда & $\begin{array}{c}\text { затрудняюсь } \\
\text { ответить }\end{array}$ \\
\hline экономика & 100,0 & - & - \\
\hline менеджмент & 93,3 & 3,3 & 3,3 \\
\hline управление персоналом & 100,0 & - & - \\
\hline государственное и муниципальное управление & 100,0 & - & - \\
\hline реклама и связи с общественностью & 93,8 & 6,3 & - \\
\hline психология & 100,0 & - & - \\
\hline психолого-педагогическое образование & 93,3 & 6,7 & - \\
\hline социология & 100,0 & - & - \\
\hline туризм & 100,0 & - & - \\
\hline международные отношения & 69,2 & 15,4 & 15,4 \\
\hline зарубежное регионоведение & 100,0 & - & - \\
\hline юриспруденция & 95,9 & 2,5 & 1,6 \\
\hline культурология & 100,0 & - & - \\
\hline Bcezo & 96,3 & 2,3 & 1,4 \\
\hline
\end{tabular}

\begin{tabular}{|c|c|c|c|}
\hline \multirow{2}{*}{$\begin{array}{c}\text { Укажите Ваше направление подготовки } \\
\text { (спечиальность) }\end{array}$} & \multicolumn{3}{|c|}{$\begin{array}{l}\text { Если ли у Вас возможность поджлючения } \\
\kappa \text { электронно-библиотечной системе вуза } \\
\text { из любой точки, где есть сеть Интернет? }\end{array}$} \\
\hline & $\partial a, b c e z \partial a$ & $\begin{array}{c}\text { не всегда } \\
\text { получается }\end{array}$ & нет \\
\hline экономика & 100,0 & - & - \\
\hline менеджмент & 100,0 & - & - \\
\hline управление персоналом & 100,0 & - & - \\
\hline государственное и муниципальное управление & 100,0 & - & - \\
\hline реклама и связи с общественностью & 100,0 & - & - \\
\hline психология & 94,7 & 5,3 & - \\
\hline психолого-педагогическое образование & 100,0 & - & - \\
\hline социология & 100,0 & - & - \\
\hline туризм & 100,0 & - & - \\
\hline международные отношения & 53,8 & 46,2 & - \\
\hline зарубежное регионоведение & 100,0 & - & - \\
\hline
\end{tabular}




\begin{tabular}{|l|c|c|c|}
\hline юриспруденция & 95,1 & 2,5 & 2,5 \\
культурология & 75,0 & 25,0 & - \\
Всего & 94,3 & 4,8 & 0,9 \\
\hline
\end{tabular}

\begin{tabular}{|c|c|c|}
\hline \multirow{2}{*}{$\begin{array}{c}\text { Укажите Ваше направление подготовки } \\
\text { (специальность) }\end{array}$} & \multicolumn{2}{|c|}{$\begin{array}{c}\text { Аоступны ли Вам учебники, } \\
\text { методические пособия, лекции и т. д. } \\
\text { в электронной и печатной формах? }\end{array}$} \\
\hline & $\partial a$ & Hem \\
\hline экономика & 100,0 & - \\
\hline менеджмент & 100,0 & - \\
\hline управление персоналом & 100,0 & - \\
\hline государственное и муниципальное управление & 100,0 & - \\
\hline реклама и связи с общественностью & 100,0 & - \\
\hline психология & 100,0 & - \\
\hline психолого-педагогическое образование & 100,0 & - \\
\hline социология & 100,0 & - \\
\hline туризм & 100,0 & - \\
\hline международные отношения & 100,0 & - \\
\hline зарубежное регионоведение & 100,0 & - \\
\hline юриспруденция & 99,2 & 0,8 \\
\hline культурология & 100,0 & - \\
\hline Bcero & 99,7 & 0,3 \\
\hline
\end{tabular}

\begin{tabular}{|c|c|c|c|c|}
\hline \multirow[b]{2}{*}{$\begin{array}{c}\text { Укажите Ваше направление } \\
\text { подготовки (спечиальность) }\end{array}$} & \multicolumn{4}{|c|}{ Как Вы можете оченить их качество? } \\
\hline & $\begin{array}{c}\text { полностью } \\
\text { удовле- } \\
\text { творен }(a)\end{array}$ & $\begin{array}{c}\text { удовлетво- } \\
\text { рен(а) } \\
\text { в большей мере }\end{array}$ & $\begin{array}{c}\text { не в полной } \\
\text { мере }\end{array}$ & $\begin{array}{l}\text { не удовле- } \\
\text { творен(а) }\end{array}$ \\
\hline экономика & 98,3 & 1,7 & - & - \\
\hline менеджмент & 93,3 & 6,7 & - & - \\
\hline управление персоналом & 80,0 & 20,0 & - & - \\
\hline $\begin{array}{l}\text { государственное и муниципальное } \\
\text { управление }\end{array}$ & 96,2 & 3,8 & - & - \\
\hline $\begin{array}{l}\text { реклама и связи с обществен- } \\
\text { ностью }\end{array}$ & 100,0 & - & - & - \\
\hline психология & 89,5 & 10,5 & - & - \\
\hline
\end{tabular}




\begin{tabular}{|l|c|c|c|c|}
\hline психолого-педагогическое & & & & - \\
образование & 93,3 & - & 6,7 & - \\
социология & 100,0 & - & - & - \\
туризм & 100,0 & - & - & - \\
международные отношения & 53,8 & 38,5 & 7,7 & - \\
зарубежное регионоведение & 100,0 & - & - & 1,7 \\
юриспруденция & 79,3 & 18,2 & 0,8 & \\
культурология & 71,4 & 28,6 & - & 0,6 \\
Всего & 86,0 & 12,6 & 0,9 & \\
\hline
\end{tabular}

\begin{tabular}{|c|c|c|c|}
\hline \multirow{2}{*}{$\begin{array}{c}\text { Укажите Ваше направление подготовки } \\
\text { (спечиальность) }\end{array}$} & \multicolumn{3}{|c|}{$\begin{array}{c}\text { Удовлетворяет ли Вашим потребностям } \\
\text { компьютерное обеспечение учебного } \\
\text { прочесса? }\end{array}$} \\
\hline & $\partial a$ & нет & не знаю \\
\hline экономика & 100,0 & - & - \\
\hline менеджмент & 100,0 & - & - \\
\hline управление персоналом & 100,0 & - & - \\
\hline государственное и муниципальное управление & 100,0 & - & - \\
\hline реклама и связи с общественностью & 100,0 & - & - \\
\hline психология & 94,7 & - & 5,3 \\
\hline психолого-педагогическое образование & 100,0 & - & - \\
\hline социология & 100,0 & - & - \\
\hline туризм & 100,0 & - & - \\
\hline международные отношения & 100,0 & - & - \\
\hline зарубежное регионоведение & 100,0 & - & - \\
\hline юриспруденция & 90,2 & 4,1 & 5,7 \\
\hline культурология & 100,0 & - & - \\
\hline Bcero & 96,3 & 1,4 & 2,3 \\
\hline
\end{tabular}

\begin{tabular}{|c|c|c|c|c|}
\hline \multirow{2}{*}{$\begin{array}{c}\text { Укажите Ваше направление } \\
\text { подготовки (спечиальность) }\end{array}$} & \multicolumn{4}{|c|}{$\begin{array}{c}\text { Удовлетворяет ли Вас качество аудиторий, помещении } \\
\text { кафедр, фондов читального зала и библиотеки, учебных } \\
\text { лабораторий и оборудования? }\end{array}$} \\
\hline & $\begin{array}{l}\text { не удовле- } \\
\text { творяют }\end{array}$ & $\begin{array}{l}\text { не в полной } \\
\text { мере удовле- } \\
\text { творяют }\end{array}$ & \begin{tabular}{|c|} 
в большей \\
степени удов- \\
летворяют
\end{tabular} & $\begin{array}{c}\text { удовлетво- } \\
\text { ряют }\end{array}$ \\
\hline экономика & - & - & 37,3 & 62,7 \\
\hline менеджмент & - & - & 13,3 & 86,7 \\
\hline
\end{tabular}




\begin{tabular}{|l|c|c|c|c|}
\hline управление персоналом & - & - & 26,7 & 73,3 \\
государственное и муниципальное & & & 11,5 & 88,5 \\
управление & - & - & 25,0 & 75,0 \\
реклама и связи с обществен- & & - & - & 100,0 \\
ностью & - & - & - & 100,0 \\
психология & - & - & - & 100,0 \\
психолого-педагогическое & - & - & 66,7 & 33,3 \\
образование & - & - & 46,2 & 53,8 \\
социология & - & - & - & 100,0 \\
туризм & - & - & 25,4 & 70,5 \\
международные отношения & - & 2,5 & 35,7 & 64,3 \\
зарубежное регионоведение & 1,6 & - & 24,5 & 74,1 \\
юриспруденция & 0,6 & 0,9 & & \\
культурология & & & - & \\
Всего & - & - & - & \\
\hline
\end{tabular}

\begin{tabular}{|c|c|c|c|c|}
\hline \multirow{2}{*}{$\begin{array}{c}\text { Укажите Ваше направление } \\
\text { подготовки (спечиальность) }\end{array}$} & \multicolumn{4}{|c|}{$\begin{array}{c}\text { Очените, как организована самостоятельная работа } \\
\text { студентов в университете: есть ли для әтого помещения } \\
\text { компьютерное обеспечение и т. д.? }\end{array}$} \\
\hline & $\begin{array}{l}\text { не удовле- } \\
\text { творен(а) }\end{array}$ & $\begin{array}{l}\text { не в полной } \\
\text { мере удовле- } \\
\text { творен (a) }\end{array}$ & \begin{tabular}{|c|} 
в большец̆ \\
степени удов- \\
летворен (a)
\end{tabular} & $\begin{array}{c}\text { удовле- } \\
\text { творен(а) }\end{array}$ \\
\hline экономика & - & - & 11,9 & 88,1 \\
\hline менеджмент & - & - & 6,7 & 93,3 \\
\hline управление персоналом & - & - & 6,7 & 93,3 \\
\hline $\begin{array}{l}\text { государственное и муниципальное } \\
\text { управление }\end{array}$ & - & - & 11,5 & 88,5 \\
\hline $\begin{array}{l}\text { реклама и связи с обществен- } \\
\text { ностью }\end{array}$ & - & 6,3 & 18,8 & 75,0 \\
\hline психология & - & - & - & 100,0 \\
\hline $\begin{array}{l}\text { психолого-педагогическое } \\
\text { образование }\end{array}$ & - & - & 6,7 & 93,3 \\
\hline социология & - & - & - & 100,0 \\
\hline туризм & - & - & 33,3 & 66,7 \\
\hline международные отношения & - & 7,7 & 23,1 & 69,2 \\
\hline зарубежное регионоведение & - & - & - & 100,0 \\
\hline юриспруденция & 1,7 & - & 24,0 & 74,4 \\
\hline культурология & - & - & 32,1 & 67,9 \\
\hline Bcero & 0,6 & 0,6 & 16,9 & 82,0 \\
\hline
\end{tabular}




\begin{tabular}{|c|c|c|c|}
\hline \multirow{2}{*}{$\begin{array}{c}\text { Укажите Ваше направление подготовки } \\
\text { (спечиальность) }\end{array}$} & \multicolumn{3}{|c|}{$\begin{array}{c}\text { Влияет ли Ваше мнение на повышение качества } \\
\text { образовательных ресурсов, используемых } \\
\text { при реализачии программь? }\end{array}$} \\
\hline & $\partial a$ & нет & $\begin{array}{c}\text { затрудняюсь } \\
\text { ответить }\end{array}$ \\
\hline экономика & 98,3 & - & 1,7 \\
\hline менеджмент & 86,7 & 6,7 & 6,7 \\
\hline управление персоналом & 86,7 & 6,7 & 6,7 \\
\hline $\begin{array}{l}\text { государственное и муниципальное } \\
\text { управление }\end{array}$ & 100,0 & - & - \\
\hline реклама и связи с общественностью & 56,3 & - & 43,8 \\
\hline психология & 94,7 & - & 5,3 \\
\hline психолого-педагогическое образование & 86,7 & 6,7 & 6,7 \\
\hline социология & 100,0 & - & - \\
\hline туризм & 33,3 & - & 66,7 \\
\hline международные отношения & 46,2 & - & 53,8 \\
\hline зарубежное регионоведение & 100,0 & - & - \\
\hline юриспруденция & 78,7 & 4,9 & 16,4 \\
\hline культурология & 75,0 & - & 25,0 \\
\hline Всего & 83,2 & 2,8 & 14,0 \\
\hline
\end{tabular}

\begin{tabular}{|c|c|c|c|}
\hline \multirow{2}{*}{$\begin{array}{c}\text { Укажите Ваше направление подготовки } \\
\text { (специальность) }\end{array}$} & \multicolumn{3}{|c|}{$\begin{array}{c}\text { Удовлетворены ли Вы тем, что обучаетесь в дан- } \\
\text { ном вузе и на данном направлении подготовки } \\
\text { (спечиальности)? }\end{array}$} \\
\hline & $\begin{array}{c}\text { полностьюю } \\
\text { удовле- } \\
\text { мворен(а) }\end{array}$ & $\begin{array}{l}\text { частично удов- } \\
\text { летворен(а) }\end{array}$ & не знаю \\
\hline экономика & 100,0 & - & - \\
\hline менеджмент & 96,7 & - & 3,3 \\
\hline управление персоналом & 100,0 & - & - \\
\hline $\begin{array}{l}\text { государственное и муниципальное } \\
\text { управление }\end{array}$ & 100,0 & - & - \\
\hline реклама и связи с общественностью & 100,0 & - & - \\
\hline психология & 100,0 & - & - \\
\hline психолого-педагогическое образование & 93,3 & 6,7 & - \\
\hline социология & 100,0 & - & - \\
\hline туризм & 100,0 & - & - \\
\hline международные отношения & 84,6 & 15,4 & - \\
\hline зарубежное регионоведение & 66,7 & 33,3 & - \\
\hline юриспруденция & 92,6 & 5,7 & 1,6 \\
\hline культурология & 96,4 & 3,6 & - \\
\hline Bcero & 95,7 & 3,4 & 0,9 \\
\hline
\end{tabular}




\begin{tabular}{|c|c|c|c|c|}
\hline \multirow{2}{*}{$\begin{array}{c}\text { Укажите Ваше направление } \\
\text { подготовки (спещиальность) }\end{array}$} & \multicolumn{4}{|c|}{ Очените качество образования по программе в челом } \\
\hline & $\begin{array}{l}\text { неудовлетво- } \\
\text { рительно }\end{array}$ & $\begin{array}{c}\text { удовлетвори- } \\
\text { тельно }\end{array}$ & хорошо & отлично \\
\hline экономика & - & - & 18,6 & 81,4 \\
\hline менеджмент & - & - & 20,0 & 80,0 \\
\hline управление персоналом & - & - & 20,0 & 80,0 \\
\hline $\begin{array}{l}\text { государственное и муниципальное } \\
\text { управление }\end{array}$ & - & - & 7,7 & 92,3 \\
\hline $\begin{array}{l}\text { реклама и связи с обществен- } \\
\text { ностью }\end{array}$ & - & - & 12,5 & 87,5 \\
\hline психология & - & - & 5,3 & 94,7 \\
\hline $\begin{array}{l}\text { психолого-педагогическое } \\
\text { образование }\end{array}$ & 13,3 & 6,7 & - & 80,0 \\
\hline социология & - & - & - & 100,0 \\
\hline туризм & - & - & 33,3 & 66,7 \\
\hline международные отношения & - & 15,4 & 38,5 & 46,2 \\
\hline зарубежное регионоведение & - & - & - & 100,0 \\
\hline юриспруденция & 1,6 & 3,3 & 19,7 & 75,4 \\
\hline культурология & - & - & 32,1 & 67,9 \\
\hline Bcezo & 1,1 & 1,7 & 18,5 & 78,6 \\
\hline
\end{tabular}

Обучающиеся по программам аспирантуры представлены следующим образом.

\begin{tabular}{|c|c|c|c|}
\hline \multirow{2}{*}{ Направление подготовки (спечиальность) } & \multicolumn{3}{|c|}{$\begin{array}{c}\text { Удовлетворяет ли Вас организачия } \\
\text { научно-исследовательских работ } \\
\text { по профилю Вашей подготовки? }\end{array}$} \\
\hline & $\begin{array}{c}\text { полностью } \\
\text { удовле- } \\
\text { мворен }(a)\end{array}$ & $\begin{array}{c}\text { удовле- } \\
\text { творен( }(\text { a) } \\
\text { в большей мере }\end{array}$ & $\begin{array}{c}\text { не в полной } \\
\text { мере }\end{array}$ \\
\hline психологические науки & 58,3 & 41,7 & - \\
\hline экономика & 45,5 & 54,5 & - \\
\hline социологические науки & 33,3 & 66,7 & - \\
\hline юриспруденция & 26,7 & 66,7 & 6,7 \\
\hline образование и педагогические науки & 63,6 & 36,4 & - \\
\hline политические науки и регионоведение & 100,0 & - & - \\
\hline философия, этика и религиоведение & - & 100,0 & - \\
\hline исторические науки и археология & 66,7 & 33,3 & - \\
\hline культурология & 33,3 & 66,7 & - \\
\hline Bcero & 45,1 & 53,5 & 1,4 \\
\hline
\end{tabular}




\begin{tabular}{|c|c|c|}
\hline \multirow{2}{*}{$\begin{array}{c}\text { Направление подготовки } \\
\text { (спечиальность) }\end{array}$} & \multicolumn{2}{|c|}{$\begin{array}{c}\text { Имеется ли для Вас возможность } \\
\text { бесплатных публикачий в отечественных } \\
\text { речензируемых журналах? }\end{array}$} \\
\hline & $\partial a$ & нет \\
\hline психологические науки & 100,0 & - \\
\hline экономика & 90,9 & 9,1 \\
\hline социологические науки & 100,0 & - \\
\hline юриспруденция & 100,0 & - \\
\hline образование и педагогические науки & 100,0 & - \\
\hline политические науки и регионоведение & 100,0 & - \\
\hline философия, этика и религиоведение & 100,0 & - \\
\hline исторические науки и археология & 100,0 & - \\
\hline культурология & 85,7 & 14,3 \\
\hline Bcezo & 97,2 & 2,8 \\
\hline
\end{tabular}

\begin{tabular}{|c|c|c|}
\hline \multirow{2}{*}{$\begin{array}{l}\text { Направление подготовки } \\
\text { (спечиальность) }\end{array}$} & \multicolumn{2}{|c|}{$\begin{array}{l}\text { Предоставлялась ли Вам возможность } \\
\text { выбора темь научного исследования? }\end{array}$} \\
\hline & $\partial a$ & $\begin{array}{c}\text { затрудняюсь } \\
\text { отВетить }\end{array}$ \\
\hline психологические науки & 100,0 & - \\
\hline экономика & 100,0 & - \\
\hline социологические науки & 100,0 & - \\
\hline юриспруденция & 100,0 & - \\
\hline образование и педагогические науки & 100,0 & - \\
\hline политические науки и регионоведение & 100,0 & - \\
\hline философия, этика и религиоведение & 100,0 & - \\
\hline исторические науки и археология & 100,0 & - \\
\hline культурология & 85,7 & 14,3 \\
\hline Bcero & 98,6 & 1,4 \\
\hline
\end{tabular}

\begin{tabular}{|c|c|c|c|}
\hline \multirow{2}{*}{$\begin{array}{l}\text { Направление подготовки } \\
\text { (спечиальность) }\end{array}$} & \multicolumn{3}{|c|}{$\begin{array}{l}\text { Как часто Вы принимаете участие } \\
\text { в научных семинарах, конференииях? }\end{array}$} \\
\hline & регулярно & $\begin{array}{c}\text { от случая } \\
\kappa \text { случаюо }\end{array}$ & не участьую \\
\hline психологические науки & 16,7 & 83,3 & - \\
\hline экономика & 9,1 & 63,6 & 27,3 \\
\hline социологические науки & 16,7 & 83,3 & - \\
\hline юриспруденция & 20,0 & 80,0 & - \\
\hline
\end{tabular}




\begin{tabular}{|l|c|c|c|}
\hline образование и педагогические науки & 45,5 & 54,5 & - \\
политические науки и регионоведение & 100,0 & - & - \\
философия, этика и религиоведение & 33,3 & 66,7 & - \\
исторические науки и археология & 50,0 & 50,0 & - \\
культурология & 28,6 & 71,4 & 4,2 \\
Всего & 26,4 & 69,4 & \\
\hline
\end{tabular}

\begin{tabular}{|c|c|c|c|}
\hline \multirow{2}{*}{$\begin{array}{c}\text { Направление подготовки } \\
\text { (спечиальность) }\end{array}$} & \multicolumn{3}{|c|}{$\begin{array}{c}\text { Каким образом проходит организачия } \\
\text { практик, стажировок? Места практик } \\
\text { определяются вузом? }\end{array}$} \\
\hline & вузом & находим сами & другоe \\
\hline психологические науки & 100,0 & 8,3 & 8,3 \\
\hline экономика & 81,8 & 9,1 & 9,1 \\
\hline социологические науки & 83,3 & - & 16,7 \\
\hline юриспруденция & 86,7 & 13,3 & 6,7 \\
\hline образование и педагогические науки & 100,0 & - & - \\
\hline политические науки и регионоведение & 100,0 & - & - \\
\hline философия, этика и религиоведение & 66,7 & - & 33,3 \\
\hline исторические науки и археология & 83,3 & - & 16,7 \\
\hline культурология & 85,7 & - & 14,3 \\
\hline Bcero & 88,9 & 5,6 & 9,7 \\
\hline
\end{tabular}

\begin{tabular}{|c|c|c|c|}
\hline \multirow{2}{*}{$\begin{array}{c}\text { Направление подготовки } \\
\text { (специальность) }\end{array}$} & \multicolumn{3}{|c|}{$\begin{array}{c}\text { Удовлетворяет ли Вас качество } \\
\text { аудиторий, помешений кафедр, фондов } \\
\text { читального зала и библиотеки, учебных } \\
\text { лабораторий и оборудования? }\end{array}$} \\
\hline & $\begin{array}{c}\text { не удовлетво- } \\
\text { рлют }\end{array}$ & $\left|\begin{array}{c}\text { в большей } \\
\text { степени } \\
\text { удовлетворяют }\end{array}\right|$ & $\begin{array}{c}\text { удовле- } \\
\text { творяют }\end{array}$ \\
\hline психологические науки & - & 75,0 & 25,0 \\
\hline экономика & - & 36,4 & 63,6 \\
\hline социологические науки & - & 50,0 & 50,0 \\
\hline юриспруденция & - & 53,3 & 46,7 \\
\hline образование и педагогические науки & - & 27,3 & 72,7 \\
\hline политические науки и регионоведение & - & - & 100,0 \\
\hline философия, этика и религиоведение & - & 33,3 & 66,7 \\
\hline исторические науки и археология & - & 33,3 & 66,7 \\
\hline культурология & 14,3 & 57,1 & 28,6 \\
\hline Bcero & 1,4 & 47,2 & 51,4 \\
\hline
\end{tabular}




\begin{tabular}{|c|c|c|}
\hline \multirow[t]{2}{*}{$\begin{array}{c}\text { Направление подготовки } \\
\text { (спечиальность) }\end{array}$} & \multicolumn{2}{|c|}{$\begin{array}{c}\text { Удовлетворяет ли Вашим } \\
\text { потребностям компьютерное } \\
\text { обеспечение учебного прочесса? }\end{array}$} \\
\hline & $\partial a$ & не знаю \\
\hline психологические науки & 91,7 & 8,3 \\
\hline экономика & 100,0 & - \\
\hline социологические науки & 100,0 & - \\
\hline юриспруденция & 100,0 & - \\
\hline образование и педагогические науки & 100,0 & - \\
\hline политические науки и регионоведение & 100,0 & - \\
\hline философия, этика и религиоведение & 66,7 & 33,3 \\
\hline исторические науки и археология & 100,0 & - \\
\hline культурология & 100,0 & - \\
\hline Bcero & 97,2 & 2,8 \\
\hline
\end{tabular}

\begin{tabular}{|c|c|c|}
\hline \multirow[t]{2}{*}{$\begin{array}{c}\text { Направление подготовки } \\
\text { (спечиальность) }\end{array}$} & \multicolumn{2}{|c|}{$\begin{array}{c}\text { Имеете ли Вы возможность доступа к } \\
\text { современным профессиональным базам } \\
\text { данньх и информащионным справочным } \\
\text { системам? }\end{array}$} \\
\hline & $\partial a$ & Hem \\
\hline психологические науки & 100,0 & - \\
\hline экономика & 100,0 & - \\
\hline социологические науки & 100,0 & - \\
\hline юриспруденция & 100,0 & - \\
\hline образование и педагогические науки & 100,0 & - \\
\hline политические науки и регионоведение & 100,0 & - \\
\hline философия, этика и религиоведение & 100,0 & - \\
\hline исторические науки и археология & 100,0 & - \\
\hline культурология & 85,7 & 14,3 \\
\hline Bcezo & 98,6 & 1,4 \\
\hline
\end{tabular}

\begin{tabular}{|c|c|c|}
\hline \multirow{2}{*}{$\begin{array}{c}\text { Направление подготовки } \\
\text { (спечиальность) }\end{array}$} & \multicolumn{2}{|c|}{$\begin{array}{l}\text { Аоступны ли для Вас учебники, } \\
\text { методические пособия, лекчии и т. д. } \\
\text { в әлектронной и печатной форлах? } \\
\text { Как Вь можете оченить их качество? }\end{array}$} \\
\hline & $\begin{array}{c}\text { да, полностью } \\
\text { удовлетворен( } а)\end{array}$ & $\begin{array}{c}\text { да, yдовлетво- } \\
\text { рен(a) в большей } \\
\text { мере }\end{array}$ \\
\hline психологические науки & 41,7 & 58,3 \\
\hline экономика & 63,6 & 36,4 \\
\hline
\end{tabular}




социологические науки
юриспруденция
образование и педагогические науки
политические науки и регионоведение
философия, этика и религиоведение
исторические науки и археология
культурология
Всего

\begin{tabular}{|c|c|}
50,0 & 50,0 \\
40,0 & 60,0 \\
72,7 & 27,3 \\
100,0 & - \\
- & 100,0 \\
66,7 & 33,3 \\
42,9 & 57,1 \\
51,4 & 48,6 \\
\hline
\end{tabular}

\begin{tabular}{|c|c|c|}
\hline \multirow{2}{*}{$\begin{array}{c}\text { Направление подготовки } \\
\text { (спечиальность) }\end{array}$} & \multicolumn{2}{|c|}{$\begin{array}{c}\text { Очените, как организована } \\
\text { самостоятельная работа в вузе: } \\
\text { есть ли для этого помешения, } \\
\text { компьютерное обеспечение и т. Ә.? }\end{array}$} \\
\hline & $\begin{array}{c}\text { в большей степени } \\
\text { удовлетворен }(\text { a) }\end{array}$ & удовлетворен(а) \\
\hline психологические науки & 58,3 & 41,7 \\
\hline экономика & 54,5 & 45,5 \\
\hline социологические науки & 50,0 & 50,0 \\
\hline юриспруденция & 57,1 & 42,9 \\
\hline образование и педагогические науки & 27,3 & 72,7 \\
\hline политические науки и регионоведение & 100,0 & - \\
\hline философия, этика и религиоведение & 66,7 & 33,3 \\
\hline исторические науки и археология & 33,3 & 66,7 \\
\hline культурология & 57,1 & 42,9 \\
\hline Bcero & 50,7 & 49,3 \\
\hline
\end{tabular}

\begin{tabular}{|c|c|c|}
\hline \multirow[t]{2}{*}{$\begin{array}{c}\text { Направление подготовки } \\
\text { (специальность) }\end{array}$} & \multicolumn{2}{|c|}{\begin{tabular}{|c|} 
Располагает ли Ваша образовательная \\
организачия лабораторным \\
оборудованием, необходимым \\
для проведения экспериментов \\
по Вашей теме научного исследования?
\end{tabular}} \\
\hline & да, в полном объеме & да, частично \\
\hline психологические науки & 25,0 & 75,0 \\
\hline экономика & 10,0 & 90,0 \\
\hline социологические науки & 20,0 & 80,0 \\
\hline юриспруденция & 35,7 & 64,3 \\
\hline образование и педагогические науки & 45,5 & 54,5 \\
\hline политические науки и регионоведение & 100,0 & - \\
\hline
\end{tabular}


философия, этика и религиоведение

исторические науки и археология

культурология

Bcezo

\begin{tabular}{l|l}
66,7 & 33,3 \\
50,0 & 50,0 \\
42,9 & 57,1 \\
34,8 & 65,2
\end{tabular}

\begin{tabular}{|l|c|c|}
\hline \multicolumn{1}{|c|}{$\begin{array}{c}\text { Hаправление подготовки } \\
\text { (специальность) }\end{array}$} & \multicolumn{2}{c|}{$\begin{array}{c}\text { Назначен ли Bам } \\
\text { научный руководитель? Его звание }\end{array}$} \\
\cline { 2 - 3 } & да, кандидат наук & да, доктор наук \\
\hline психологические науки & 8,3 & 91,7 \\
экономика & 18,2 & 81,8 \\
социологические науки & - & 100,0 \\
юриспруденция & 6,7 & 93,3 \\
образование и педагогические науки & - & 100,0 \\
политические науки и регионоведение & - & 100,0 \\
философия, этика и религиоведение & - & 100,0 \\
исторические науки и археология & 16,7 & 83,3 \\
культурология & 14,3 & 85,7 \\
Всего & 8,3 & 91,7 \\
\hline
\end{tabular}

\begin{tabular}{|c|c|c|}
\hline \multirow{2}{*}{$\begin{array}{c}\text { Направление подготовки } \\
\text { (спечиальность) }\end{array}$} & \multicolumn{2}{|c|}{$\begin{array}{c}\text { Удовлетворяет ли Вас качество } \\
\text { педагогического состава, } \\
\text { реализующего програлму? }\end{array}$} \\
\hline & да, полностью & $\partial a$ \\
\hline психологические науки & 41,7 & 58,3 \\
\hline экономика & 36,4 & 63,6 \\
\hline социологические науки & 50,0 & 50,0 \\
\hline юриспруденция & 40,0 & 60,0 \\
\hline образование и педагогические науки & 70,0 & 30,0 \\
\hline политические науки и регионоведение & 100,0 & - \\
\hline философия, этика и религиоведение & 33,3 & 66,7 \\
\hline исторические науки и археология & 66,7 & 33,3 \\
\hline культурология & 28,6 & 71,4 \\
\hline Всего & 46,5 & 53,5 \\
\hline
\end{tabular}




\begin{tabular}{|c|c|c|c|}
\hline \multirow[t]{2}{*}{$\begin{array}{c}\text { Направление подготовки } \\
\text { (спечиальность) }\end{array}$} & \multicolumn{3}{|c|}{$\begin{array}{c}\text { Очените качество образования } \\
\text { по программе в челом }\end{array}$} \\
\hline & $\begin{array}{c}\text { удовлетвори- } \\
\text { тельно }\end{array}$ & хорошо & отлично \\
\hline психологические науки & 41,7 & 16,7 & 41,7 \\
\hline экономика & 27,3 & 18,2 & 54,5 \\
\hline социологические науки & 50,0 & - & 50,0 \\
\hline юриспруденция & 46,7 & 6,7 & 46,7 \\
\hline образование и педагогические науки & 27,3 & 9,1 & 63,6 \\
\hline политические науки и регионоведение & - & - & 100,0 \\
\hline философия, этика и религиоведение & 33,3 & 66,7 & - \\
\hline исторические науки и археология & 33,3 & - & 66,7 \\
\hline культурология & 57,1 & 14,3 & 28,6 \\
\hline Bcero & 38,9 & 12,5 & 48,6 \\
\hline
\end{tabular}

\section{ЗАКАЮЧЕНИЕ}

Аанные по магистрантам и аспирантам нередко содержат похожие процентные данные, которые могут восприниматься как повторы, - 33,3\%, 50\%, 66,7\%, 100\%. Это явление отражает три обстоят ельства.

Первое определяется тем, что небольшие цифры магистрантов и аспирантов разбиваются на группы по направлениям подготовки, так что в каждой из таких групп может быть 1-3 опрашиваемых, и мнение небольшого числа (в абсолютных измерениях) респондентов в процентах даст картину вроде той, что обозначена выше.

Второе отражает низкую чувствительность инструментария при большом числе параметров (иногда - неопределенном, обозначенном «и т. А.»). Например, сложный по составу компонентов вопрос «Оцените, как организована самостоятельная работа в вузе: есть ли для этого помещения, компьютерное обеспечение и т. А.?» предусматривает один из двух ответов: «в большей степени удовлетворен(а)» и «удовлетворен(а)». Очевидно, что выбор невелик, и эксперт (исследователь) волен интерпретировать полученные данные по своему усмотрению.

Но более интересно третье обстоятельство, не учитывавшееся, видимо, при составлении инструментария. В представленных данных отражен Хоторнский эффект (Hawthorne effect), который в социологии понимается как постановка более высоких оценок респондентами по измеряемых в эмпирическом исследовании показателям, которая возникает как результат включенности в эксперимент и соответствующего интереса к нему. Этот феномен впервые был выявлен в экспериментах, проведенных в 1920-1930-е годы в компании «Вестерн Электрик» в американском городе Хоторн близ Чикаго. Собственники заводов, производивших телефоны, пригласили ученых, рассчитывая с помощью науки повысить производительность труда рабочих. Здесь были получившие позже известность психологи, социологи, теоретики в области управления производством Аж. Хоманс, Ф. Аж. Ротлисбергер и др. Руководивший исследованием со 2-го этапа Элтон Мэйо и его ученики по Гарварду (среди них и Ротли- 
сбергер) на основе выявления этого әффекта пришли к концепции «человеческих отношений», сменившей в менеджменте опору на тейлоризм (Мауо, 2014). Была показана роль неформальных групп в поддержании, увеличении и в целом регулировании производительности труда, но главное - в теории и на практике был совершен переход от ориентации на индивидуального работника к группам работников, малым группам в первую очередь, стало изучаться групповое сознание в применении к организации производства. Многочисленная критика выводов Мэйо в последующие годы, основанная на невоспроизводимости тех же результатов, что были получены в Хотторнских экспериментах (Jones, 1992), не привела к отбрасыванию самого принципа, который породил новую концепцию менеджмента.

В нашем случае Хотторнский эффект раскрылся с другой своей стороны: обучающиеся в вузе, который признали «своим», склонны несколько повышать оценки своей удовлетворенности вузом и его образовательными программами, зная, что их оценки будут учтены при принятии решения о судьбе вуза. В сравнении с исследованием студенческих оценок учебно-воспитательного процесса в МосГУ, проведенного в 2019 г. почти в то же время, но где фактора внешнего управленческого решения не было, оценки выше примерно на 2-4\%. В главном оценки почти совпадают. Так, в частности, в ответе на вопрос «Насколько комфортно Вы ощущаете себя в нашем университете?» 47,1\% студентов выбрали высшую оценку ( «5»), 48,1\% - высокую оценку ( «4»), что в сумме составляет $95,2 \%$. А в представленном выше исследовании это сопоставимо с данными при ответе студентов на вопрос «Удовлетворены ли Вы тем, что обучаетесь в данном вузе и на данном направлении подготовки (специальности)? (здесь, правда, опять дается одна оценка по двум разным показателям). Высшую из предлагаемых оценок («полностью удовлетворен(а)») ставят 95,7\% респондентов. В других случаях разрыв данных несколько больше, так что Хоторнский эффект надо учитывать при анализе данных.

Но более значимо то, что здесь обнаруживаются феномены, раскрываемые тезаурусным подходом (Ауков В., Ауков Вл., 2013, 2014). Напомним, что в социологии тезаурус понимается как «полный систематизированный свод освоенных сочиальньм субъектом знаний, существенных для него как средство ориентачии в окружаюшей среде, а сверх этого также знаний, которые непосредственно не связаны с ориентачионной функиией, но расширяют понимание субъектом себя и мира, дают импульсь для радостной, интересной, многообразной жизни» (Ауков В., Ауков Вл., 2013: 3. Курсив авторов). Систематизация этого свода знаний идет не по линии от общего к частному, а по модели «свой-чужой» (с учетом сопоставления тезаурусов по модели «свой-чужой-чуждый»). В применении к студентам представление о «своем» вузе очень важно. Есть и стремление некоторой части студентов защитить «свой» вуз от недружественных «объективных» проверок внешними контролерами. Иногда это означает стремление не замечать очевидных промахов вуза, недостатков его образовательных программ, а то и неосвоенность будущих профессиональных требований и надежду на покладистость преподавателей в отношении к нежелающим учиться.

Однако есть важная сторона поддержки «своего» вуза: возникающая у студента идентификация с ним. Она во многом определяет успех в учебе, интерес к осваиваемым знаниям, понимания себя и своего места в социальной среде - нынешней и будущей. На этом направлении и должна сосредоточиться воспитательная работа лучших вузов. 


\section{СПИСОК АИТЕРАТУРЫ}

Большой психологический словарь (2003) / под ред. Б. Г. Мещерякова, В. П. Зинченко. М. : Прайм-Еврознак. 632 с.

Ааль, В. И. (2007) Толковый словарь живого великорусского языка : в 4 т. / совмещ. ред. изданий В. И. Ааля и И. А. Бодуэна де Куртене в соврем. написании. М. : ОАМА Медиа Групп. T. $2.672 \mathrm{c}$.

Ауков, В. А., Ауков, Вл. А. (2013) Тезаурусы II: Тезаурусный подход к пониманию человека и его мира. М. : ИзА-во Национального института бизнеса. 640 с.

Ауков, В. А., Ауков, Вл. А. (2014) Методология тезаурусного подхода: стратегия понимания // Знание. Понимание. Умение. № 1. С. 18-35.

Словарь русского языка (1983) : в 4 т. / под ред. А. П. Евгеньевой. М. : Русский язык. Т. 2. $736 \mathrm{c}$.

Толковый словарь русского языка (2007) : в 4 т. / под ред. А. Н. Ушакова. М. : Терра - Книжный Клуб. Т. 2. 520 с.

Eisenblatt, S. (2002) The Straight Road to Happiness: A Personal Guide to Enable Us to Overcome Tendencies which Block Our Natural Flow of Happiness and to Explore New Horizons of Inner Joy. Jerusalem (Israel) : Nanuet (NY) : Feldheim. 458 p.

Jones, S. R. G. (1992) Was there a Hawthorne effect? // American Journal of Sociology. Vol. 98 (3). P. 451-468. DOI: $10.1086 / 230046$

Mayo, E. (2014) The Social Problems of an Industrial Civilisation. London : Routledge. 200 p.

Seligman, M., Csikszentmilhalyi, M. (2000) Positive Psychology// American Psychologist. Vol. 55 (1). P. 5-10. DOI: 10.1037/0003-066x.55

Аата поступления: 12.06.2019 2.

\section{ORGANISATION OF EDUCATIONAL PROCESS AT THE UNIVERSITY: STUDENTS' SATISFACTION AND EXPECTATIONS}

\section{S. V. LUKOV \\ MOSCOW UNIVERSITY FOR THE HUMANITIES}

The paper presents the results of a survey among students at Moscow University for the Humanities, which was conducted in February and March 2019. The survey was part of the university's state accreditation, using tools developed by Rosobrnadzor and was meant to reveal the degree of students' satisfaction with the university and the quality of education it provides. Such a survey is not an empirical sociological research; nevertheless, its results can be used in the sociology of youth, sociology of education, etc. for secondary data analysis. It is shown that the disadvantages of the tools (lack of social and demographic block, attributing one scale to two questions, incomplete scales) in this case do not prevent this mass being used in the aspect of revealing satisfaction and expectations when matching the data both within the survey (considering the difference between academic programmes) and without it (considering the data from other surveys).

However, the Hawthorne effect must be taken into account, which, in this case, is linked with the identification of a considerable number of students with "their" university. This somewhat raises (by 2-4 per cent) the university satisfaction indices as well as its educational facilities and activity.

Keywords: youth; students; educational process; quality of education; expectations; satisfaction

\section{REFERENCES}

Bol'shoi psikbologicheskii slovar' (2003) / ed. by B. G. Meshcheriakov and V. P. Zinchenko. Moscow, Praim-Evroznak. 632 p. (In Russ.).

Dal', V. I. (2007) Tolkovyi slovar' zhivogo velikorusskogo iazyka: in 4 vol. Moscow,OLMA Media Grupp. Vol. 2. 672 p. (In Russ.).

Lukov, V. A. and Lukov, Vl. A. (2013) Tezaurusy II: Tezaurusnyi podkbod k ponimaniiu cheloveka i ego mira. Moscow, Izd-vo Natsional'nogo instituta biznesa. 640 p. (In Russ.). 
Lukov, V. A. and Lukov, Vl. A. (2014) Metodologiia tezaurusnogo podkhoda: strategiia ponimaniia. Znanie. Ponimanie. Umenie, no. 1, pp. 18-35. (In Russ.).

Slovar' russkogo iazyka (1983) : in 4 vol. / ed. by A. P. Evgen'eva. Moscow, Russkii iazyk. Vol. 2. 736 p. (In Russ.).

Tolkovyi slovar' russkogo iazyka (2007) : in 4 vol. / ed. by D. N. Ushekov. Moscow, Terra Knizhnyi Klub. Vol. 2. 520 p. (In Russ.).

Eisenblatt, S. (2002) The Straight Road to Happiness: A Personal Guide to Enable Us to Overcome Tendencies wbich Block Our Natural Flow of Happiness and to Explore New Horizons of Inner Joy. Jerusalem (Israel), Nanuet (NY), Feldheim. 458 p.

Jones, S. R. G. (1992) Was there a Hawthorne effect? American Journal of Sociology, vol. 98 (3), pp. 451-468. DOI: $10.1086 / 230046$

Mayo, E. (2014) The Social Problems of an Industrial Civilisation. London : Routledge. 200 p.

Seligman, M., Csikszentmilhalyi, M. (2000) Positive Psychology. American Psychologist, vol. 55 (1), pp. 5-10. DOI: 10.1037/0003-066x.55

Submission date: 12.06 .2019$.

Ауков Сергей Валерьевич - кандидат социологических наук, начальник отдела прикладной социологии Центра социологии молодежи Института фундаментальных и прикладных исследований Московского гуманитарного университета. Адрес: 111395, Россия, г. Москва, ул. Юности, д. 5. Тел.: +7 (499) 374-75-95. Эл. адрес: sv-lukov@mail.ru

Lukov Sergey Valeryevich, Candidate of Sociology, Head, Department of Applied Sociology, Centre for Sociology of Youth, Institute of Fundamental and Applied Studies, Moscow University for the Humanities. Postal address: 5, Yunosti St., Moscow, Russian Federation, 111395. Tel.: +7 (499) 374-75-95. E-mail:sv-lukov@mail.ru 